\title{
STUDY OF HORMONE RECEPTOR STATUS IN CARCINOMA BREAST
}

\author{
Kiran Somani ${ }^{1}$, Abhishek Kansal2, Raghvendra Singh ${ }^{3}$, Akhilesh Patel ${ }^{4}$, Sanjay Datey ${ }^{5}$
}

1 Professor, Department of Surgery, Sri Aurobindo Medical College and Postgraduate Institute, Indore, Madhya Pradesh, India. ${ }^{2}$ Associate Professor, Department of Surgery, Sri Aurobindo Medical College and Postgraduate Institute, Indore, Madhya Pradesh, India.

${ }^{3}$ Senior Resident, Department of Surgery, Sri Aurobindo Medical College and Postgraduate Institute, Indore, Madhya Pradesh, India. 4Junior Resident, Department of Surgery, Sri Aurobindo Medical College and Postgraduate Institute, Indore, Madhya Pradesh, India. 5 Professor, Department of Surgery, Sri Aurobindo Medical College and Postgraduate Institute, Indore, Madhya Pradesh, India.

\section{BACKGROUND}

ABSTRACT

Breast cancer is the most common cancer in women. The mortality due to this disease is decreasing in western countries, because of early detection and effective systemic adjuvant therapy. In India incidence is still increasing, therefore it is important to identify high-risk patient groups for whom adjuvant therapy is beneficial.

This study was carried out at our centre to find hormone receptor status of patients with carcinoma breast, as it could have significant implications on the management and prognosis.

\section{MATERIALS AND METHODS}

This descriptive study was conducted during a period of two years from 1 ${ }^{\text {st }}$ May 2012 to 30 th $^{\text {th }}$ April 2014 at Sri Aurobindo Institute of Medical Sciences, whereby 50 consecutive patients of diagnosed carcinoma of breast were admitted in the Department of General Surgery. A detailed clinical history was taken and thorough clinical examination was done and was subjected to surgery (Modified Radical Mastectomy) after routine investigations. The specimen sent for histopathology examination along with ER/PR/HER-2 receptor analysis by immunohistochemistry. The collected data was tabulated and analysed by using simple statistical methods.

\section{RESULTS}

In the present study, all 50 patients were female and the mean age of patients was 49.88 , ranging from 21 to 78 years. $48 \%$ were pre-menopausal and 54\% were post-menopausal. Right sided carcinoma breast was seen in $62 \%$ patients with upper outer quadrant lesions in 54\% patients. Multicentric carcinoma was found in 6\% patients. 40\% patients were in stage 2B, 22\% in stage $2 \mathrm{a}, 28 \%$ in stage $3 \mathrm{a}, 8 \%$ in stage $3 \mathrm{~b}$ and $2 \%$ in stage $3 \mathrm{c}$ according to TNM staging. ER receptor was positive in $62 \%$ patients, PR receptor was positive in $54 \%$ of patients. HER-2 receptor was positive in $48 \%$ patients. Triple negative disease in $26 \%$ of patients. Infiltrating ductal carcinoma was found in $76 \%$ patients and $18 \%$ had intraductal carcinoma. We found 3 patients with lobular carcinoma.

\section{CONCLUSION}

In the present study, $90 \%$ patients were there in stage IIA to IIIA, i.e. presenting in advanced stage of the disease with $75 \%$ patients having diagnosis of infiltrating ductal carcinoma and 25\% patients had triple negative disease indicating bad prognosis. Breast cancer is a heterogeneous disease with a wide spectrum of clinical, pathological and molecular features and application of ta rgeted therapy has played an important role in breast cancer survival rate during the past two decades, so we conclude the assessment of ER/PR/HER-2 receptor is desirable in management of carcinoma breast patients in India.

\section{KEY WORDS}

Carcinoma Breast, Oestrogen and Progesterone Receptors.

HOW TO CITE THIS ARTICLE: Somani K, Kansal A, Singh R, et al. Study of hormone receptor status in carcinoma breast. J. Evolution Med. Dent. Sci. 2018;7(38):4188-4191, DOI: 10.14260/jemds/2018/936

\section{BACKGROUND}

The breast cancer is now the most common malignancy among Indian women. ${ }^{1,2}$ The role of hormone receptor as prognostic and therapeutic tool is widely accepted. Clinical trial has also shown the surgical advantage for patient with receptor positive status by treatment with adjuvant hormonal or chemotherapeutic regimen. ${ }^{3}$

'Financial or Other Competing Interest': None.

Submission 06-08-2018, Peer Review 31-08-2018,

Acceptance 06-09-2018, Published 17-09-2018.

Corresponding Author:

Dr. Abhishek Kansal,

\#103, Kunwar Princess Crown,

95-96, Srinagar Main, Indore-452010,

Madhya Pradesh, India.

E-mail: dr_kansal@yahoo.com

DOI: $10.14260 /$ jemds $/ 2018 / 936$

\section{(c) $($ ) $\$$}

It is well known that strong ER positive cases benefit from endocrine therapy alone. 4 Patients with ER/PR positive tumour have a better prognosis than the patients with negative expression of ER/PR receptors. ${ }^{5}$ Immunohistochemical analysis of these receptors is used for therapeutic and predictive purposes in routine breast cancer patient management.

\section{Objectives of the Study}

1. To study the clinical profile of the patients of Carcinoma breast with special reference to the ER, PR and HER-2 receptor status.

2. To study and implement the receptor status in the further management of patients after surgery.

\section{MATERIALS AND METHODS}

This descriptive study was conducted during a period of two years from $1^{\text {st }}$ May 2012 to 30th April 2014 at Sri Aurobindo 
Institute of Medical Sciences, whereby 50 consecutive patients of diagnosed carcinoma of breast were admitted in the Department of General Surgery. Detailed clinical histories were taken and thorough clinical examination was done and was subjected to surgery (MRM) after routine investigations. The specimens were sent for histopathology examination along with ER, PR and HER-2 receptor study by immunohistochemistry. Post-surgical treatment, i.e. chemotherapy, radiotherapy and adjuvant therapy were decided by histopathological reports and ER, PR and HER-2 receptor status. Patients with ER positive tumours were treated by tamoxifen along with chemotherapy in premenopausal women and aromatase inhibitors in postmenopausal women. Patients with HER-2 positive tumours were treated by monoclonal antibody known as trastuzumab (Herceptin). No adjuvant therapy is available for ER/PR/HER-2 negative (triple negative) tumours. 6,7

\section{RESULTS}

\begin{tabular}{|c|c|c|}
\hline Age Group (In Years) & No. & Percentage (\%) \\
\hline $21-30$ & 1 & 2.0 \\
\hline $31-40$ & 7 & 14.0 \\
\hline $41-50$ & 22 & 44.0 \\
\hline $51-60$ & 11 & 22.0 \\
\hline$>60$ & 9 & 18.0 \\
\hline Total & $\mathbf{5 0}$ & $\mathbf{1 0 0 . 0}$ \\
\hline Table 1. Distribution of Patient according to Age \\
\hline
\end{tabular}

In this study, we found $44 \%$ between ( 41 - 50 years), $22 \%$ (51 - 60 years) and 14\% (31 - 40 years). Mean age in our study group is 49.88 years.

\begin{tabular}{|c|c|c|}
\hline Menopausal Status & No. & Percentage (\%) \\
\hline Pre-menopausal & 24 & 48 \\
\hline Post-menopausal & 26 & 52 \\
\hline $\begin{array}{l}\text { Total } \\
\end{array}$ & 50 & 100 \\
\hline \multicolumn{3}{|c|}{$\begin{array}{c}\text { Table 2. Distribution of Patient according to Menopausal } \\
\text { Status }\end{array}$} \\
\hline
\end{tabular}

In this study, we found $52 \%$ are from post-menopausal status and $48 \%$ cases are pre-menopausal status.

\begin{tabular}{|c|c|c|}
\hline Site & No. & Percentage (\%) \\
\hline LIQ (Lower Inner Quadrant) & 2 & 4.0 \\
\hline LOQ (Lower Outer Quadrant) & 4 & 8.0 \\
\hline UIQ (Upper Inner Quadrant) & 15 & 30.0 \\
\hline UOQ (Upper Outer Quadrant) & 27 & 54.0 \\
\hline $\begin{array}{c}\text { UOQ/ Central (Upper Outer } \\
\text { Quadrant) }\end{array}$ & 2 & 4.0 \\
\hline Total & 50 & 100.0 \\
\hline
\end{tabular}

In this study, we found $54 \%$ cases in UOQ, $30 \%$ cases in UIQ, $8 \%$ cases in LOQ, $4 \%$ in LIQ and $4 \%$ central.

\begin{tabular}{|c|c|c|}
\hline Side & No. & Percentage (\%) \\
\hline Left & 19 & 38.0 \\
\hline Right & 31 & 62.0 \\
\hline Total & $\mathbf{5 0}$ & $\mathbf{1 0 0 . 0}$ \\
\hline \multicolumn{2}{|c|}{ Table 4. Distribution of Patient according to Side } \\
\hline
\end{tabular}

In this observation, we found $62 \%$ cases were on right side compared to left side $38 \%$.

\begin{tabular}{|c|c|c|}
\hline Number of Lesions & No. & Percentage (\%) \\
\hline One & 47 & 94.0 \\
\hline Two & 3 & 6.0 \\
\hline Total & $\mathbf{5 0}$ & $\mathbf{1 0 0 . 0}$ \\
\hline \multicolumn{3}{|c|}{ Table 5. Distribution of Patient according to Number of } \\
Lesions \\
\hline
\end{tabular}

In this observation, we found $94 \%$ cases had single lesion and rest 3\% had two lesions.

\begin{tabular}{|c|c|c|}
\hline Staging & No. & Percentage (\%) \\
\hline II A & 11 & 22.0 \\
\hline II B & 20 & 40.0 \\
\hline III A & 14 & 28.0 \\
\hline III B & 4 & 8.0 \\
\hline III C & 1 & 2.0 \\
\hline Total & $\mathbf{5 0}$ & $\mathbf{1 0 0 . 0}$ \\
\hline
\end{tabular}

Table 6. Distribution of Patient according to Staging

In our observation, we found $40 \%$ cases were stage IIB and stage IIIA $28 \%$, stage IIA $22 \%$, stage IIIB $8 \%$ and stage IIIc $2 \%$.

\begin{tabular}{|c|c|c|c|c|c|c|}
\hline & $\begin{array}{c}\text { ER } \\
+ \text { +ve }\end{array}$ & $\begin{array}{c}\text { ER } \\
\text {-ve }\end{array}$ & $\begin{array}{c}\text { PR } \\
+ \text { ve }\end{array}$ & $\begin{array}{l}\text { PR } \\
\text {-ve }\end{array}$ & $\begin{array}{c}\text { Her2 } \\
\text { +ve }\end{array}$ & $\begin{array}{c}\text { Her 2- } \\
\text { ve }\end{array}$ \\
\hline Number & 31 & 19 & 27 & 23 & 20 & 30 \\
\hline Percentage & 62.0 & 38.0 & 54.0 & 46.0 & 40.0 & 60.0 \\
\hline Total & \multicolumn{2}{|c|}{50} & \multicolumn{2}{|c|}{50} & \multicolumn{2}{|c|}{50} \\
\hline
\end{tabular}

In this observation, we found $62 \%$ were ER positive and $38 \%$ were negative, $54 \%$ were PR positive and $46 \%$ negative and $40 \%$ were HER- 2 positive and $60 \%$ negative.

\begin{tabular}{|c|c|c|}
\hline Histopathology & Total & Percentage (\%) \\
\hline Infiltrating ductal CA & 38 & 76.0 \\
\hline Intraductal CA & 9 & 18.0 \\
\hline Lobular CA & 3 & 6.0 \\
\hline Table 8. ER, PR, HER-2/In Relation to the \\
Histopathological Grade \\
\hline
\end{tabular}

In this observation we found $76 \%$ were infiltrating ductal carcinoma, $18 \%$ were intraductal carcinoma and $6 \%$ were lobular carcinoma.

\begin{tabular}{|c|c|c|c|c|c|}
\hline $\begin{array}{c}\text { ER, PR } \\
\text { Status }\end{array}$ & II A & II B & III A & III B & III C \\
\hline ER- PR- & 2 & 3 & 9 & 3 & 0 \\
\hline ER- PR+ & 0 & 0 & 2 & 0 & 0 \\
\hline ER+ PR- & 2 & 2 & 1 & 1 & 0 \\
\hline ER+ PR+ & 7 & 15 & 2 & 0 & 1 \\
\hline Total & $\mathbf{1 1}$ & $\mathbf{2 0}$ & $\mathbf{1 4}$ & $\mathbf{4}$ & $\mathbf{1}$ \\
\hline
\end{tabular}

In this study we found ER, PR positive $30 \%$, more in stage IIB compared to ER, PR negative $18 \%$ in stage IIIA.

\begin{tabular}{|c|c|c|c|c|c|}
\hline HER-2/ Status & II A & II B & III A & III B & III C \\
\hline Negative & 6 & 9 & 11 & 4 & 0 \\
\hline Positive & 5 & 11 & 3 & 0 & 1 \\
\hline Total & $\mathbf{1 1}$ & $\mathbf{2 0}$ & $\mathbf{1 4}$ & $\mathbf{4}$ & $\mathbf{1}$ \\
\hline & Table 10. HER-2/ Status in relation to Staging \\
\hline
\end{tabular}


In this study, we found HER-2 positive $22 \%$ more in stage IIB compared to HER-2 negative $22 \%$ in stage III A.

\begin{tabular}{|c|c|c|c|c|}
\hline Age Group & ER- PR- & ER- PR+ & ER+ PR- & ER+ PR+ \\
\hline $21-30$ & 0 & 0 & 0 & 1 \\
\hline $31-40$ & 1 & 0 & 0 & 12 \\
\hline $41-50$ & 4 & 2 & 2 & 6 \\
\hline $51-60$ & 8 & 0 & 4 & 1 \\
\hline$>60$ & 4 & 0 & 0 & 5 \\
\hline Total & $\mathbf{1 7}$ & $\mathbf{2}$ & $\mathbf{6}$ & $\mathbf{2 5}$ \\
\hline \multicolumn{6}{|r}{ Table 11. ER, PR Status according to Age Group } \\
\hline
\end{tabular}

In this observation we found ER, PR positive more in 3140 years' age group as compared to ER, PR negative more in 51-60 years' age group.

\begin{tabular}{|c|c|c|}
\hline Age Group & HER-2/ Negative & HER-2/ Positive \\
\hline $21-30$ & 0 & 1 \\
\hline $31-40$ & 13 & 2 \\
\hline $41-50$ & 9 & 2 \\
\hline $51-60$ & 4 & 12 \\
\hline$>60$ & 4 & 3 \\
\hline Total & $\mathbf{3 0}$ & $\mathbf{2 0}$ \\
\hline Table 12. HER-2/Status according to Age Group \\
\hline
\end{tabular}

In this observation, we found HER-2 negative cases belonged to 31 - 40 years' age group as compared to HER-2 positive cases belonged to 51 - 60 years' age group.

\section{DISCUSSION}

ER, PR and HER-2 have practical and vital implications in the diagnosis, management and prognosis in breast cancer. ER, PR and HER-2 negative (Triple negative) disease has the worst outcome. The selected cases were grouped according to ER, PR and HER-2 receptor positive and negative both the groups compared.

Total number of ER, PR and HER-2 receptor positive and negative cases- In our study we found 50\% (25 out of 50) ER, PR positive cases of carcinoma breast and HER-2 positive $40 \%$ (20 out 50) and ER-PR negative 34\% (17 out of 50) and HER-2 positive $28 \%$ (14 out of 50) ER, PR with HER-2 negative $26 \%$ (13 out of 50 ). Similar results have been reported by Slamon et al, ${ }^{8}$ Borg et al in 1990,9 Almasri and Hamad et al 2005.10

Age distribution of various ER, PR and HER-2 positive and negative cases - In our study we found ER-PR positive more in 31 - 40 years' age group. HER-2 positive more in $51-60$ years compared to HER-2 negative more in 31 - 40 years' age group. Similar results have been reported by Bermon et al 2000 and Hamad et al 2005.

Pre- and post-menopausal status of ER, PR and HER-2 positive or negative cases- In our study, we found ER-positive more in pre-menopausal patients 38\% (19 out of 50) and PRpositive more in pre-menopausal patients $30 \%$ (15 out of 50). ER-PR positive more in pre-menopausal 30\% (15 out of 50 ), HER- 2 positive $22 \%$ more in post-menopausal compared to HER-2 negative more in pre-menopausal $42 \%$. Our findings did not correlate with McCann et al in 1991.11

Stage distribution of ER/PR and HER-2 positive and negative cases- In our county we found ER-PR positive belonged to stage II A 30\% (17 out of 50) and ER-PR negative in stage III A $18 \%$ ( 9 out of 50 ). HER-2 positive belonged to stage II B $22 \%$ (11 out of 50). HER-2 negative belonged to stage III A $22 \%$ (11 out of 50) and rest belonged to stage II A and III B. Our finding correlates with finding of Krogerus et al 2001.12

Relationship between various histopathological form with ER, PR and HER-2 positive and negative cases- In our study, we found all cases of ER, PR and HER-2 positive group belonged to infiltrating duct carcinoma. Majority of ER-PR negative and HER-2 negative infiltrating duct carcinoma were $74 \%$ (37 out 50 ) and few cases of intraductal carcinoma were $18 \%$ ( 9 out of 50 ) and rest lobulated carcinoma of $8 \%$ (4 out of 50) were also found. Our findings correlate with Almasri and Hamad et al in 2005. ${ }^{10}$

\section{CONCLUSION}

Total number of ER, PR and HER-2 positive cases (Good prognosis) are $28 \%$ as compared to ER, PR and HER-2 negative cases $26 \%$ triple negative (Poor prognosis). ER-PR positive cases belonged to younger age group between 31- 40 years compared to ER-PR negative belonging to 51 - 60 years' age group. HER-2 positive were more in $51-60$ years' age group compared to HER-2 negative more in 41 - 50 years' age group. ER, PR and HER-2 positive cases belonged to stage II A and II $\mathrm{B}$ as compared to ER, PR and HER-2 negative cases belonged to stage III A and III B. ER-PR positive and HER-2 negative cases mostly belonged to pre-menopausal age group compared to ER-PR negative and HER-2 positive belonged to post-menopausal status. Breast cancer is a heterogeneous disease with a wide spectrum of clinical, pathological and molecular features and application of targeted therapy has played an important role in breast cancer survival rate during the past two decades. So, we conclude the assessment of ER/PR/HER-2 receptor is desirable in management of carcinoma breast patients in India. However, as sample size is a limitation in this study, a larger study on a larger population would be necessary to draw statistically significant conclusions.

\section{REFERENCES}

[1] Kamath R, Mahajan KS, Ashok L, et al. A study on risk factors of breast cancer among patients attending the tertiary care hospital, in Udupi district. Indian J Community Med 2013;38(2):95-9.

[2] Khokhar A. Breast cancer in India: where do we stand and where do we go? Asian Pac J Cancer Prev 2012;13(10):4861-6.

[3] Dunnwald LK, Rossing MA, Li CI. Hormone receptor status, tumor characteristics and prognosis: a prospective cohort of breast cancer patients. Breast Cancer Res 2007;9(1):R6.

[4] Allred DC, Harvey JM, Berardo M, et al. Prognostic and predictive factors in breast cancer by immunohistochemical analysis. Mod Pathol 1998;11(2):155-68.

[5] Bardou JV, Arpino G, Elledge RM. Progesterone receptor status significantly improves outcome prediction over estrogen receptor status alone for adjuvant endocrine therapy in two large breast cancer databases. J Clin Oncol 2003;21(10):1973-9. 
[6] Fadda GM, Santeufemia DA, Basso SM, et al. Adjuvant treatment of early breast cancer in the elderly. Med Chem 2016;12(3):280-4.

[7] Gupta D, Gupta V, Marwah N, et al. Correlation of hormone receptor expression with histologic parameters in benign and malignant breast tumors. Iranian Journal of Pathology 2015;10(1):23-34.

[8] Slamon DJ, Clark GM, Wong SG, et al. Human breast cancer: correlation of relapse and survival with amplification of the HER-2/ oncogene. Science 1987;235(4785):177-82.

[9] Borg A, Haile RW, Malone KE, et al. Characterization of BRCA1 and BRCA2 deleterious mutations and variants of unknown clinical significance in unilateral and bilateral breast cancer: the WECARE study. Hum Mutat 2010;31(3):E1200-40.
[10] Almasri NM, Al Hamad M. Immunohistochemical evaluation of human epidermal growth factor receptor 2 and estrogen and progesterone receptors in breast carcinoma in Jordan. Breast Cancer Res 2005;7(5):R598-R604.

[11] McCann. The role of HER2 in early breast cancer metastasis and the origins of resistance to HER2targeted therapies. 2009.

[12] Krogerus LA, Leivonen M. Her-2/neu oncogene expressionin advanced breast cancer. Cancer Detect Prev 2001;25:1-7. 